\title{
Peranan Account Officer Pada PT. Bank Perkreditan Rakyat Ganto Nagari 1954 Lubuk Alung
}

\author{
Iis Sholihat, Romi Susanto \\ Akademi Keuangan dan Perbankan Padang \\ romisusanto@akbpstie.ac.id
}

\begin{abstract}
The purpose of this study is how the role of the Account Officer at PT. BPR Ganto Nagari 1954 Lubuk Alung. The research method is Field Research, which is meant by this method is a direct review of the object of research chosen to examine the results of secondary data, Library Research, what is meant by this method is an investigation carried out through literature or scientific books and writings which has a connection with the discussion that was carried out. Data Analysis Method for analyzing research data, the author uses descriptive analysis, which describes the overall role of the Account Officer at PT. BPR Ganto Nagari 1954 Lubuk Alung. Conclusion In the credit analysis submitted by the customer, before making a decision whether the credit proposal is accepted or rejected, the Account Officer uses several credit analyzes including 5C analysis, namely: Character aims to determine the nature / character of prospective debtors, Capacity to determine the customer's ability to run the business and credit return process, Capital aims to determine the working capital requirements needed by customers, Condition to find out the business conditions / future business prospects, Collateral to find out the value of collateral / collateral offered whether it has covered the amount of credit.
\end{abstract}

Keywords: Account Officer, Bank

\section{PENDAHULUAN}

Bank merupakan lembaga perantara (Financial Intermediaries) sebagai Sarana pendukung yang sangat vital untuk menunjang kelancaran perekonomian. Banyaknya bank saat ini membuat persaingan semakin ketat dan berlomba untuk memperoleh peringkat paling baik dimata masyarakat, khususnya PT. BPR Ganto Nagari 1954 Lubuk Alung. Oleh sebab itu diperlukan strategi yang baik oleh masing-masing bank guna meningkatkan laba dan memiliki kualitas yang baik. Salah satu cara bank yang tepat adalah dengan memanfaatkan peranan seorang Account Officer dibank atau instansi tersebut. Hampir disetiap bank memiliki seorang Account Officer dalam memberikan pelayanan terhadap nasabah yang datang secara baik dan langsung, karena pelayanan Account Officer sangat penting dan tulang punggung kegiatan operasional dalam perbankan. Tanpa adanya peranan seorang Account Officer maka sangat berpengaruh terhadap perkembangan perusahaan. Secara umum pengertian Account Officer adalah orang yang bertugas mencari nasabah yang layak sesuai dengan kriteria peraturan bank, menilai, mengevaluasi, mengusulkan berapa kredit yang akan diberikan yang berada pada bagian perkreditan yang memiliki tugas dan kewajiban secara umum adalah mengelola kredit nasabahnya. Sebelum Account Officer akan membuat perencanaan, usaha apa saja yang layak dibiayai diwilayahnya dan berapa kira-kira dana yang diperlukan untuk menyalurkan kredit tersebut dan kemudian akan melakukan kunjungan keusaha nasabah, melakukan wawancara, menggali sebetulnya apa yang diperlukan oleh 
nasabah tersebut. Agar pelayanan yang diberikan berjalan dengan baik, hubungan antara Account Officer dengan nasabah diibaratkan suami istri. Jika Account Officer memilih usaha yang tepat untuk nasabahnya maka usaha tersebut meningkat dan berjalan dengan lancar serta Bank tempat Account Officer bekerja akan memperolah laba. Namun jika usaha nasabah mengalami penurunan akan mempengaruhi keadaan Account Officer. Demikian juga dengan Account Officer, jika usaha nasabah turun maka Account Officer yang baik akan segera mengevaluasi apa yang yang menjadi penyebabnya, apakah persaingan yang ketat sehingga kalah bersaing dipemasaran. Menggalakkan kemampuan Account Officer agar berkualitas merupakan kebutuhan bank, agar dapat menyalurkan pinjaman sesuai sasaran serta dilihat dari sisi debitur (nasabah) pinjaman tadi dapat meningkatkan usahanya serta meningkatkan penyerapan tenaga kerja. Pembinaan terhadap nasabah dapat dimulai darinasabah yang kecil, yang secara pasti akan meningkat kemampuan usahanya dan juga meningkatkan jumlah pinjamannya dan pada saat nasabah menjadi besar maka akan terjalin hubungan timbale balik yang positif antara bank dan nasabah, serta diperoleh nasabah-nasabah yang loyal bagi bank tersebut. Oleh karena itu, faktor adanya Account Officer yang berkualitas sangat berperanan dalam menunjang perkembangan bank dan disatu sisi dapat meningkatkan kemampuan sector riil dalam penyerapan tenaga kerja. Dari uraian diatas, dan untuk memberikan gambaran yang jelas tentang peranan Account Officer yang baik bagi seorang nasabah dan untuk menambah pemahaman masyarakat tentang apa dan bagaimana peranan Account Officer tersebut.

Berdasarkan latar belakang diatas, penulis membuat perumusan yaitu Bagaimana peranan Account Officer pada PT. BPR Ganto Nagari 1954 Lubuk Alung.

\section{TINJAUAN PUSTAKA \\ Pengertian Account Officer}

Account Officer atau disingkat AO mulai lazim dikenal didunia perbankan sejak 1 juni 1983 disaat kompetensi didunia perbankan semakin kompetitif dalam pengarahan dan penyaluran dana pihak ketiga, maka seluruh bank berlomba memberikan pelayanan yang terbaik bagi nasabah dengan selalu mengedepankan kepentingan nasabah, maka kini para bank memiliki slogan "pelayanan yang berorientasi kepada nasabah" atau lebih dikenal dengan customer service oriented. Menurut Deddi Anggadiredja, Account Officer memiliki 2 pengertian aspek yang berbeda. Pertama sebagai suatu system, Account Officer merupakan suatu bagian integral dari suatu system manajemen modern dibidang manajemen pemesaran yang efektif. Kedua sebagai orang yang mengemban fungsi Account Officer, merupakan aparat bank yang dalam melaksanakan pekerjaannya berusaha menciptakan ramuan tentang berbagai produk dan jasa bank yang disesuaikan dengan kebutuhan pasar. Menurut Edratna, menyatakan bahwa Account Officer adalah orang yang bertugas sejak mencari nasabah yang layak sesuai criteria peraturan bank, menilai, mengevaluasi, mengusulkan besarnya kredit yang diberikan. Secara umum Account Officer adalah pegawai atau karyawan bank yang berada pada bagian perkreditan, yang memiliki tugas dan kewajiban secara umum adalah mengelola kredit nasabahnya. Account Officer bertugas mencari nasabah yang layak, sesuai dengan kriteria peraturan bank menilai mengevaluasi, menganalisa dan mengusulkan besarnya kredit yang diberikan. Untuk mendapatkan seorang AO yang berkualitas, diperlukan pendididkan yang memadai dan jam terbang agar bisa mengenali usaha yang layak dibiayai. Sebelum Account Officer akan membuat perencanaan, usaha apa saja yang layak dibiayai diwilayahnya danberapa kira-kira dana yang diperlukan untuk menyalurkan kredit tersebut dan kemudian akan melakukan kunjungan keusaha nasabah, melakukan wawancara, menggali sebetulnya apa yang diperlukan oleh nasabah tersebut. 
Account Officer juga sekaligus menjadi konsultan. Disini Account Officer memandu nasabah agar dapat membuat neraca perkiraaan usaha, serta arus kas kemampuan membayarnya. AO juga harus sensitif apakah nasabah mengatakan yang sebenarnya kemudian melakukan analisa. Selanjutnya AO akan mengusulkan dalam bentuk memorandum analisis kredit kepada atasannya dan atasan akan meneruskan kedalam komite kredit (loan commitee) untuk mendapat putusan, berupa persetujuan maupun penolakan. Hubungan AO dengan nasabah sangat erat, Jika AO memilih usaha yang tepat maka usaha akan berjalan dengan lancar, dan usaha akan meningkat dan membesar serta bank tempat AO bekerja akan memperoleh laba. Namun jika usaha nasabah mengalami penurunan akan mempengaruhi kelangsungan hidup bank. Demikian apabila portofolio nasabah yang dibina oleh $\mathrm{AO}$ semua dalam kondisi lancar, maka perusahaan akan memetik laba dari interest margin (pendapatan laba). Namun sebaliknya kegagalan pembinaan AO terhadap nasabahnya juga dapat menyebabkan pendapatan bank menurun.

\section{Syarat Menjadi Seorang Account Officer}

Account Officer atau AO bank merupakan ujung tombak bisnis bank yang bergerak dalam bidang penyaluran pembiayaan (kredit).

a. Syarat Kecakapan Umum

Memiliki jaringan yang luas, maksudnya adalah memiliki sumber data yang baik sehingga tidak akan mengalami kesulitan untuk memasarkan produk pembiayaan / kredit.

Memiliki pengetahuan umum yang memadai, Hal ini bisa saja nasabah mengajukan pembiayaan yang sama sekali AO tidak mengetahui bisnis nasabah. AO harus mencari prospek bisnis nasabah sehingga kerjasama pembiayaan akan saling menguntungkan.

Memiliki mental baja, maksudnya karena tugas AO adalah sangat beresiko, memanggul untung-rugi sebuah bank, tentu saja mental kuat harus dimiliki.

b. Syarat Kecakapan Khusus

Analisis yang baik, memang tugas utama seorang AO selain memasarkan produk pembiayaan, ketajaman analisis seorang AO akan sangat membantu bank memperoleh nasabah yang baik, sehingga keuntungan bank meningkat dan otomatis bank sebagai penyalur dana masyarakat (nasabah), nasabah memperoleh bagi hasil yang bagus.

Mau meningkatkan kemampuan dan pengetahuan, Karena bisa jadi AO akan menemukan banyak bisnis yang belum dikuasai. Inilah keunggulan AO bisa belajar banyak tentang bisnis.

Mencari nasabah, proses awal seorang AO menganalisa adalah dari nasabah yang mengajukan, biasanya nasabah yang baik adalah yang dicari, maksudnya carilah nasabah bukan menunggu nasabah dibank.

\section{Tugas dan Tanggung Jawab Account Officer}

Inti dari tugass $\mathrm{AO}$ adalah melakukan pemasaran produk perbankan terutama produk yang berkaitan dengan kredit.

Tugas pokok seorang AO adalah sbb:

1. Mencari nasabah (debitur) yang layak sesuai criteria peraturan bank.

2. Melakukan interview atau wawancara awal kepada calon debitur serta pengisian aplikasi permohonan kredit serta menjelaskan perhitungan kredit kepada calojn debitur.

3. Memberikan penjelasan tentang syarat, peraturan dan ketentuan umum kredit yang berlaku di bank. 
4. Mengumpulkan dan melengkapi seluruh dokumen yang diperlukan dari calon debitur untuk proses kredit serita memastikan seluruh data informasi yang diterima telah diyakini kebenarannya dan seluruh copy dokumen yang diterima telah sesuai dengan aslinya.

5. Melaporkan dan menginformasikan kepada kepala bidang kredit tentang calon debitur untuk dilakukan kunjungan atau peninjauan langsung ketempat tinggal atau tempat usaha (survey lapangan) dari calon debitur.

6. Membuat atau melakukan penilaian, mengevaluasi serta menganalisa keuangan, arus kas, kebutuhan kredit serta tujuan penggunaan kredit oleh calon debitur serta melakukan trade checking dan BI checking calon debitur.

7. Membuat memorandum persetujuan kredit atau rekomendasi kredit kepada pejabat pemutus kredit untuk dapat diberikan keputusan kredit yaitu disetujui, ditolak, atau ditangguhkan.

8. Apabila memorandum kredit atau rekomendasi kredit disetujui, dokumen calon debitur diserahkan kepada bagian administrasi kredit untuk proses pencarian kredit.

9. Memonitoring pembayaran kredit dan kolektibilitas pembayaran debitur.

10. Melakukan penagihan terhadap debitur yang terlambat membayar atau debitur bermasalah.

11. Menjaga kualitas kredit (NPL) yang telah ditargetkan oleh Direksi.

Tugas tambahan Seorang Account Officer adalah sebagai berikut:

a. Melaksanakan tugas tambahan yang diberikan oleh kepala bidang kredit dan direksi, baik lisan maupun tertulis yang berkaitan dengan operasional Bank.

b. Ikut serta dalam komite kredit.

c. Melakukan kerjasama antar unit kerja demi kelancaran tugas dalam operasional Bank.

Tanggung Jawab seorang Account Officer:

a) Account Officer bertanggung jawab penuh terhadap debitur yang dikelolanya mulai dari memproses kredit debitur untuk direalisasi sampai kredit debitur tersebut lunas.

b) Account Officer (AO) kredit bertanggung jawab kepada direksi melalui kepala bidang kredit.

\section{Fungsi Account Officer}

Fungsi Account Officer adalah pegawai atau karyawan bank yang berada pada bagian perkreditan, yang memiliki tugas dan kewajiban secara umum adalah mengelola kredit nasabahnya. Namun fungsi Account Officer secara keseluruhan yaitu:

1. Tahap Permohonan Kredit

Dalam tahap ini, AO bertugas mencari prospek calon debitur untuk memenuhi target kerja yang ditetapkan.

2. Tahap Pengusulan Kredit

Setelah AO melakukan fungsi pemasaran, maka hasilnya adalah AO memperoleh calon debitur yang ingin memperoleh kredit bank untuk menambah modal usahanya.

3. Tahap Pemberian Fasilitas Kredit

Setelah melalui proses pemberian kredit dan kredit memperoleh persetujuan antuk direalisasi, maka dengan demikian nasabah dapat segera menikmati fasilitas kredit sesuai dengan kebutuhannya.

4. Tahap Perpanjangan Fasilitas Kredit

Fasilitas kredit baik itu Kredit Modal Kerja (KMK) maupun Kredit Investasi (KI) masing-masing memiliki jangka waktu tertentu. Bila kredit untuk modal kerja lazimnya berjangka waktu 12 bulan bisa diperpanjang dengan (revolving), sedangkan untuk kredit investasi disesuaikan dengan periode investasinya. 


\section{Cara Menjadi Account Officer}

1. Kenali produk yang akan ditawarkan kepada calon nasabah.

2. Gunakan bahasa yang mudah dimengerti oleh calon nasabah.

3. Jadilah informan sekaligus pendengar yang baik.

4. Selalu tersenyum kepada calon debitur.

5. Memiliki database yang cukup banyak.

\section{Peranan Seorang Account Officer}

a. Mengelola Account

Seorang Account Officer berperan untuk membina nasabah agar mendapatkan efisiensi dan optimalisasi dari setiap transaksi keuangan yang dilakukan tanpa meninggalkan tanggung jawabnya sebagai personil bank.

b. Mengelola Produk

Seorang Account Officer harus mampu mengatasi kemungkinan pemakaian berbagai produk yang paling sesuai untuk kebutuhan nasabahnya.

c. Mengelola Kredit

Account Officer berperan untuk melakukan pemantauan atas pinjaman yang diberikan kepada nasabah agar nasabah selalu memenuhi komitmen atas pinjamannya.

d. Mengelola Penjualan

Seorang Account Officer pada dasarnya merupakan ujung tombak bank dalam memasarkan produknya, maka seorang AO harus memiliki salesmanship yang memadai untuk dapat memasarkan produk yang ditawarkan.

e. Mengelola Profitabilitas

Seorang Account Officer juga berperan dalam menentukan keuntungan yang diperoleh bank. Dengan demikian, ia harus yakin bahwa segala yang dilakukan berada dalam suatu kondisi yang memberikan keuntungan kepada bank.

\section{METODE PENELITIAN}

Metode penelitian yang dilakukan adalah

\section{Metode Pengumpulan Data}

\section{a. Penelitian Lapangan}

Yang dimaksud dengan metode ini adalah peninjauan langsung ke objek penelitian yang dipilih untuk meneliti hasil data sekunder.

b. Penelitian Kepustakaan

Yang dimaksud dengan metode ini adalah penyelidikan yang dilakukan melalui kepustakaan ataupun buku-buku ilmiah dan tulisan-tulisan yang ada hubungan nya dengan pembahasan yang dilakukan.

\section{Metode Analisis Data}

Untuk menganalisa data penelitian, penulis menggunakan analisa deskriftif, yaitu menggambarkan secara keseluruhan peranan Account Officer di PT. BPR Ganto Nagari 1954 Lubuk Alung.

\section{ANALISA DAN PEMBAHASAN \\ Analisis Kredit}

Analisis kredit atau penilaian kredit adalah suatu proses yang dimaksudkan untuk menganalisa atau menilai suatu permohonan kredit yang diajukan oleh calon debitur sehingga memberikan keyakinan kepada pihak bank bahwa proyek yang akan dibiayai dengan kredit bank cukup layak (feasible). Pelaksanaan analisis kredit berpedoman pada UU No. 10 Tahun 1988 tentang Perubahan UU No. 7 Tahun 1992 tentang Perbankan, khususnya Pasal 1 Ayat (11), Pasal 8 dan Pasal 29 Ayat (3). Dalam melakukan penilaian 
terhadap hasil pembuktian apakah berkas-berkas yang diajukan pemohon sesuai dengan bukti lapangan, kemudian account officer membuat usulan komite pemutus kredit lapangan, kemudian Account Officer membuat usulan ke komite pemutus kredit mengenai diterima atau ditolak kredit yang diajukan. Untuk menghindari maupun memperkecil resiko kredit yang mungkin terjadi, karena dalam pemberian kredit mengandung suatu kredit (degree of risk) tertentu, maka permohonan kredit harus dinilai dengan pedoman analisa kredit yang mengandung unsur 5C yang dilakukan oleh analis kredit, yaitu:

1. Character / Watak

Penilaian watak calon nasabah didasarkan hubungan yang telah terjalin antara calon nasabah dengan relasi, Bank atau pihak ketiga lainnya melalui informasi yang didapat dari berbagai pihak yang dipercaya, sehingga bank dapat menyimpulkan bahwa calon nasabah adalah berwatak baik dan tidak menyulitkan Bank dikemudian hari.

2. Capacity / Kemampuan

Penilaian terhadap calon nasabah kredit dalam hal kemampuan memenuhi kewajiban yang telah disepakati dalam perjanjian pinjaman atau akad kredit, yakni melunasi pokok pinjaman disertai bunga sesuai dengan ketentuan dan syarat-syarat yang diperjanjikan.

3. Capital / Modal

Pembiayaan suatu proyek yang akan dijalankan debitur tidak seluruhnya berasal dari bank, tetapi dibiayai bersama antara bank dan debitur.

4. Condition of Economy / Kondisi usaha

Penilaian melalui analisa terhadap keadaan pasar regional, nasional, maupun internasional pada masa lalu, saat ini dan kemungkinan masa datang, juga dilihat dari bagaimana keadaan usaha terhadap lingkungan dan pemerintah.

5. Collateral / Agunan

Agunan dibutuhkan untuk berjaga-jaga kemungkinan terjadinya penyimpangan terhadap penilaian atas faktor diatas yang mengakibatkan tidak sanggupnya nasabah untuk membayar kembali kreditnya. Penilaian agunan ini berupa bentuk barang agunan, bukti kepemilikan, nilai agunan dan pengikatannya.

Setelah menganalisa kredit atau unsur 5C tersebut dalam permohonan kredit, bank juga harus memperhatikan aspek-aspek pertimbangan kredit untuk menilai kelayakan suatu usaha yang akan dibiayai oleh kredit bank. Aspek-aspek tersebut meliputi:

a. Aspek Umum atau Manajemen

Aspek ini menggambarkan tentang riwayat hidup, riwayat pendidikan, pengalaman kerja, reputasi, kemampuan perencanaan, kemampuan kerjasama, intregitas dan pengalaman usaha.

b. Aspek Pemasaran

Aspek ini menggambarkan tentang produk yang dihasilkan, daerah pemasaran, tipe konsumen dan volume pasar.

c. Aspek Teknis atau Produksi

Aspek ini meliputi perencanaan dalam segi teknis atau fisik dari suatu proyek atau usaha calon mitra dengan tujuan untuk menghasilkan produk yang dikehendaki.

d. Aspek Keuangan Aspek ini meliputi analisa neraca, analisa laba rugi, dan analisa rasio keuangan.

e. Aspek Yuridis

Aspek ini meliputi legalitas usaha, status hukum calon nasabah, dan kapasitas kewenangan.

f. Aspek Sosial Ekonomi

Aspek ini meliputi penerapan tenaga kerja, pengaruh proyek terhadap lingkungan, tidak bertentangan dengan ketentuan yang berlaku. 


\section{Prinsip Dasar Pemberian Kredit}

berikut:

Berbagai aspek yang harus diperhatikan dalam pemberian kredit diantara sebagai

1. Karakter dari debitur harus menjadi pertimbangan pertama

Bila ada keraguan akan integritas dan itikad baik dari debitur, account officer tidak perlu capek-capek melakukan analisis yang lain lagi, tolak dengan tegas proposal yang diajukan.

2. Kualitas lebih penting daripada kuantitas

Beberapa account officer mulai mengesampingkan kualitas dari kredit yang diberikan hanya demi mengejar target yang belum tercapai.

3. Account officer harus melakukan antisipasi bukan reaksi

Analis kredit harus terus menerus memonitor (memantau) kredit yang diberikan. Setiap perubahan yang terjadi dilingkungan debitur harus diperhatikan.

4. Account officer adalah seorang businessman

Analis kredit adalah orang yang mewakili bank untuk melakukan transaksi dengan para nasabahnya. Sebagai businessman yang baik, analis kredit harus tahu kapan melakukan bisnis, kapan tidak melakukan bisnis, dan kapan harus melakukan bisnis yang sedikit saja. Analis kredit harus bisa membaca keadaan.

5. Bila ada konflik kepentingan pribadi, serahkan proposal kredit ke Analis Kredit lain Dalam mengevaluasi suatu proposal kredit, AO mungkin akan menemui situasi dimana ia berada dalam posisi yang serba salah, misalnya yang mengajukan kredit adalah calon mertua, teman dekat dan lain-lain. Hal ini menimbulkan konflik kepentingan antara hubungan social dengan profesionalisme.

\section{Dasar Penyaluran Kredit}

Bagi Debitur bertujuan untuk membantu pengembangan usahanya dengan membiayai suatu kegiatan usaha yang bersifat produktif atau investasi untuk menunjang kegiatan usaha atau untuk memenuhi kebutuhan konsumtif dengan sumber pengembaliannya dari hasil yang produktif.

1. Bagi Bank untuk mencari keuntungan dan meningkatkan kesejahteraan pemilik dan karyawan.

2. Bagi Pemerintah membantu peningkatan laju pembangunan, penerimaan pajak serta memperluas kesempatan kerja.

3. Secara Umum berorientasi kepada kegiatan usaha yang bertujuan untuk meningkatkan kesejahteraan masyarakat.

\section{Prosedur atau Tahapan Pemberian Kredit}

Dalam rangka menerapkan prinsip kehati-hatian, maka dalam setiap pemberian kredit harus mengikuti prosedur pemberian kredit yang sehat yang terdiri dari 5 tahap yaitu pendekatan dan negosiasi kepada calon debitur, analisa dan investigasi kredit, administrasi persetujuan kredit, pengikatan dan administrasi pencairan kredit dan tahap yang terakhir adalah monitoring kredit.

1. Tahap Permohonan Kredit

Meminta calon debitur untuk mengajukan permohonan kredit dengan mengisi formulir permohonan kredit yang telah disediakan serta melengkapi data-data yang diperlukan sehubungan dengan permohonan kredit. Data atau informasi yang diberikan calon debitur antara lain: Nama pemohon, Nama ahli waris, Nama orangtua kandung pemohon, Alamat pemohon, Jenis usaha, Jumlah permohonan, Jangka waktu, Rencana penggunaan, Agunan yang diberikan dan lain-lain dengan melampirkan :

a. Kartu identitas diri (KTP) yang masih berlaku

b. Kartu keluarga (KK) / surat nikah 
c. Surat keterangan usaha

d. Surat bukti kepemilikan agunan (BPKB, STNK / Sertifikat Tanah

e. Pas foto debitur, foto agunan, dan denah lokasi usaha / tempat tinggal

Permohonan kredit tersebut kemudian diregistrasi didalam buku yang telah ditetapkan untuk itu, kemudian diposisikan oleh pejabat yang berwenang untuk kemudian didistribusikan kepada unit kerja atau petugas yang ditunjuk untuk memprosesnya.

2. Tahap Analisis Kredit

Setelah permohonan kredit diterima oleh petugas atau account officer yang ditunjuk, kegiatan berikutnya adalah melakukan analisis atau identifikasi atas permohonan tersebut. Adapun langkah-langkah yang perlu diperhatikan dalam membuat analisa kredit yang terkait dengan pemohon sebagai berikut:
a. Pemeriksaan kelengkapan permohonan kredit
b. Pengumpulan data dan informasi
c. Penyusunan laporan analisa kredit
d. Rekomendasi kredit

3. Tahap Keputusan atau Persetujuan Kredit

Setelah rekomendasi kredit yang diajukan oleh Analis Kredit pada pejabat kredit, maka keputusan atau persetujuan kredit dapat dilakukan melalui :

a. Komite Kredit

Komite kredit memberikan tanggapan atas hasil analisa kredit yang dilaksanakan Account Officer dalam bentuk : tambahan informasi baru, pertanyaan atas hal yang diragukan sehingga ada kesimpulan atas permohonan kredit tersebut.

b. Pejabat Kredit atau Direksi

Keputusan atau persetujuan kredit oleh pejabat kredit atau direksi, sesuai dengan batasan wewenang memutus kredit yang ditetapkan dengan surat keputusan sendiri.

Bentuk persetujuan kredit dapat berupa: Disetujui, Ditangguhkan atau Ditolak. Pemberitahuan persetujuan kredit dilakukan secara tertulis dengan menggunakan Surat Pemberitahuan Persetujuan Kredit (SPPK).

4. Tahap Administrasi dan Pencairan Kredit

Proses administrasi kredit atau pencairan kredit, dapat dilakukan setelah seluruh syarat-syarat dalam persetujuan serta pencairan kredit dan dokumen kredit secara yuridis telah dipenuhi administrasi kredit atau Account Officer (AO) antara lain :

a. Penandatanganan Akad Perjanjian Kredit (APK)

b. Pengikatan Agunan Kredit

c. Penandatanganan akad kredit oleh Direksi

d. Penarikan / Pencairan kredit oleh Debitur.

5. Tahap Pemantauan atau Monitoring Kredit

Dalam rangka menerapkan prinsip kehati-hatian dan mengupayakan pemberian kredit yang sehat, maka terhadap kredit yang telah dilepas harus dilakukan monitoring. Dengan demikian maka kredit-kredit yang cenderung menjadi bermasalah dapat diketahui secara rinci serta resiko-resiko kredit dapat segera diidentifikasikan dan dapat dilakukan upaya-upaya pemantauan.

Dalam memberikan kredit kepada debitur, tindakan pencegahan lebih baik daripada tindakan penanggulangan, prinsip inilah yang dipegang oleh Account Officer. Oleh karena itu, para banker dan petugas bank perlu dibekali ilmu pengetahuan. Ada beberapa tindakan yang dilakukan Account Officer untuk mencegah tindakan dalam memberikan kredit kepada debitur yaitu:

a. Berhati-hati dalam pemberian kredit 
b. Melakukan pendekatan kepada debitur

c. Mengadakan pengawasan kredit secara terus menerus

\section{KESIMPULAN DAN SARAN \\ Kesimpulan}

Setelah dilakukan analisa dan pembahasan penulis dapat menyimpulkan bahwa :

1. Dalam analisa kredit yang diajukan nasabah, sebelum pengambilan keputusan apakah proposal kredit tersebut diterima atau ditolak, Account Officer menggunakan beberapa analisa kredit antara lain analisa 5C yaitu:

a. Character bertujuan untuk mengetahui sifat/karakter calon debitur

b. Capacity untuk mengetahui kemampuan nasabah dalam menjalankan usahanya dan proses pengembalian kredit

c. Capital bertujuan untuk mengetahui kebutuhan modal kerja yang diperlukan nasabah

d. Condition untuk mengetahui kondisi usaha/prospek usaha kedepan

e. Collateral untuk mengetahui nilai jaminan/agunan yang ditawarkan apakah telah menutupi dari jumlah kredit.

2. Upaya atau tindakan yang dilakukan Account Officer dalam memberikan kedit kepada debitur adalah dengan cara:

a. Berhati-hati dalam pemberian kredit

b. Melakukan pendekatan kepada nasabah

c. Mengadakan pengawasan kredit secara terus menerus

\section{Saran}

Setelah dilakukan penelitian dan analisa kredit serta ditarik suatu kesimpulan, maka penulis memberikan saran untuk dijadikan sebagai bahan pertimbangan dan masukan kepada BPR Ganto Nagari 1954 Lubuk Alung adalah sebagai berikut:

1. Secara umum, perlu dibangun kebijakan pengelolaan dana yang tegas, jelas dan konsisten sehingga dapat menjadi pedoman standar dan komprehensif bagi Account Officer dalam menyalurkan dana yang diamanatkan oleh masyarakat yakni meliputi:

a. Meningkatkan kualitas studi kelayakan usaha

b. Prosedur pengambilan keputusan dan persetujuan pemberian kredit dengan memperhatikan tingkat resiko dan jumlah penanaman dana yang disalurkan.

2. Dalam menghadapi persaingan bisnis perbankan baik konvensional maupun syariah yng semakin ketat, bank sebaiknya tetap berpegang teguh pada prinsip kehati-hatian (prudential principle) dalam rangka persetujuan kredit. Perbankan dalam melakukan bisnis menggunakan dana pihak ketiga sehingga kualitas kredit lebih penting daripada kuantitasnya, prinsip ini hendaknya dipegang teguh oleh Account Officer terutama bila sedang dikejar target bisnis.

3. Kepada pihak manajemen PT BPR Ganto Nagari 1954 , diharapkan untuk meningkatkan kualitas training dan pelatihan agar dapat meningkatkan kinerja Account Officer serta pengamanan yang baik.

4. Sistem Monitoring yang komprehensif yang dilaksanakan secara disiplin dan konsisten sehingga dapat memantau secara dini perkembangan dan gejala-gejala nasabah yang tidak baik. Account Officer diwajibkan melakukan kunjungan ke nasabah dan wajib membuat laporan yang kemudian diarsipkan kedalam file kredit nasabah. 


\section{DAFTAR PUSTAKA}

Dendawijaya, Lukman. 2001. Manajemen Perbankan. Jakarta : Ghalia Indonesia.

Fernandes, Y. D., \& Marlius, D. (2018). Peranan Customer Service Dalam Meningkatkan Pelayanan Kepada Nasabah Pada PT. Bank Pembangunan Daerah Sumatera Barat Cabang Utama Padang. https://doi.org/10.31227/osf.io/wrh3p

Marlius, D. (2016). Pengaruh Bauran Pemasaran Jasa Terhadap Minat Nasabah Dalam Menabung Pada Bank Nagari Cabang Muaralabuh. https://doi.org/10.31227/osf.io/vdqgx

Martin, William B. 2004. Quaity Account Officer. Jakarta : Penerbit PPM.

Safitri, R. N., \& Marlius, D. (2017). Penerapan E-Banking Dalam Meningkatkan Jasa Dan Layanan Perbankan Di PT. Bank Rakyat Indonesia Cabang Padang. https://doi.org/10.31227/osf.io/gkv8t

Putra, A. M., \& Fernos, J. (2019). Pelaksanaan Pelayanan Prima Terhadap Kepercayaan Nasabah Di PT. Bank Perkreditan Rakyat Jorong Kampung Tangah Pariaman. https://doi.org/10.31227/osf.io/c3fy4

Sunarto, 2006. Account Officer. Yogyakarta : Penerbit Amus.

Susanti, F. W Ekazaputri. (2018). Service Performance Dan Kepuasan Sebagai Moderating Variabel Terhadap Loyalitas Nasabah Pada PT BPR Labuh Gunung Payakumbuh Jurnal Benefita: Ekonomi Pembangunan Manajemen Bisnis Dan Akuntansi. Volume 3. No. 3. Hal. 433-444.http://doi.org/10.22216/jbe.v3i3.3472

Undang-Undang Republik Indonesia No. 10 tahun 1998, Tentang Perubahan Undang-Undang No. 7 Tahun 1992 Tentang perbankan.

Yusuf, Jopie. 1995. Analisis Kredit Untuk Account Officer. Jakarta : PT. Gramedia Pustaka Utama. 